\title{
Tongue-coating and mixed saliva obtained from smokers and/or drinkers: nitric oxide/nitrite contents
}

\author{
Professora Mestranda Marise Ramos de Souza Oliveira (Odontologia - UniFOA) - \\ marise.souza@foa.org.br \\ Professor Pós-Doutor Marcelo Genestra (Odontologia - UniFOA) - \\ marcelo.genestra@foa.org.br
}

\begin{abstract}
Resumo
The aim of this study was to investigate comparatively the concentration of a nitrogen radical, particularly nitric oxide (NO)/nitrite $\left(\mathrm{NO}_{2}{ }^{-}\right)$, in the tongue-coating and mixed saliva obtained from smokers/non-smokers and drinkers/non-drinkers, proving the cytotoxic and cytoprotective effect of these free radicals in oral metabolism and physiophatolology of oral diseases. Masticatory (stimulated) methods were used in order to determine the salivary flow rates of 100 patients. The tongue-coating was obtained through of tongue cleaning named Kolbe's cleaner. Nitrite contents was measured spectophotometricaly by Griess method. Despite the NO been admittedly an important mediator of some physiological functions, when it is generated in excess it acts as the molecule-key of the cellular damage and tissue injury. The results point out that the association tobacco/alcohol points positive correlation between the increasing concentration of nitrogen radicals in the mixed saliva in order to favour tobacco/alcohol users, in comparison with the control group (not smokers/not drinkers). However, the $\mathrm{NO} / \mathrm{NO}_{2}^{-}$concentration in tongue-coating is worthless, comparing to mixed saliva.
\end{abstract}

Key words: tongue-coating; nitric oxide; nitrite; mixed saliva.

\section{Introduction}

Nitric oxide (NO), a nitrogen radical species short-life arginine-derived, has gained much attention by been found in a multitude of seemingly diverse cellular population. The 
NO synthesis enzyme (NOS) is responsible for NO production, and it contains three isoforms (nNOS=neuronal NOS, eNOS=endothelial NOS and iNOS=inducible NOS). The eNOS isoform represents a low-output NO pathway that is predominantly involved in homeostatic processes. Nevertheless, eNOS is increasingly been found in numerous other cellular systems (MONCADA et al., 1991). NO apparently affects a wide range of cellular functions such as cell-to-cell interactions, cytotoxicity and cytostasis, homeostatic mechanism and numerous other physiological roles. To mount evidence implicates NO in antimicrobial activity. Furthermore, low levels of NO have been implicated in cellular proliferation (BENTZ et al., 1999). NO has been proposed to represent a "two-edged-knife", with many potential pathophysiological roles been hypothesized, including carcinogenesis. In neoplasic tissues, NO has been implicated in permissive effects on the tumor growth, including mutagenecity, angiogenesis and metastasis, and also in macrophages'cytotoxicity against tumor cells and immunosuppression (FARIAS-EISNER et al., 1994; GAVILANES et al., 1999).

In most people the tongue's back surface has a thick mucous coating that contains food debris and billions of bacteria. The tongue-coating is a digestion physiological byproduct of food and fluids, where residues reach the tongue. This coating is not removed during swallowing and it's little affected by mouth rinses. The bacteria and debris in the tongue-coating putrefy and produce the foul-smelling sulfur gases that are responsible for the bad breath. According to the dentistry practice, many people who do not practice tongue cleaning have some degree of bad breath regularly detected. Many studies have shown that a proper tongue cleaning eliminates or considerably reduces the bad breath (review in GENESTRA et al., 2004). The tongue-coating color also shows the presence, absence and strength of a pathogenic factor (SOUZA \& GENESTRA, 2003). However, in literature there are few reports about the composition of the tongue- coating and it's contribution in oral injuries (PANG et al., 1998; LOHINAI et al., 2001).

Therefore, in this present study, we sought to determine the concentration of nitrogen radicals, particularly $\mathrm{NO}$ /nitrite $\left(\mathrm{NO}_{2}^{-}\right)$, in the tongue-coating and mixed saliva obtained from smokers/non smokers and drinkers/non drinkers, proving the cytotoxic and cytoprotective effect of these free radicals in oral metabolism and physiophatology of oral diseases.

\section{Materials and methods}

\section{Population's study}

One hundred subjects (male: female, 55:45), ranging from 17 to 63 years old (average age of 40 years) were recruited from Volta Redonda University Center. Each one of the participants completed a medical and dental history. To avoid interferences in the NO detection, we took as an exclusion criteria immune disorders, neoplasm, glucocorticoid treatment, and asthmatic conditions or inflammatory/infectious disease, located in the mouth. Non-smokers and non-drinkers formed the control group. The Institutional Ethics and Research Committee of Volta Redonda University Center/Oswaldo Aranha Foundation, Rio de Janeiro State, Brazil approved all protocols, and the volunteers gave informed consent before any participation. 


\section{Obtaining of saliva and tongue-coating samples}

Saliva's samples obtained through masticator (stimulated) methods were collected from healthy volunteers and placed in sterile container (GENESTRA \& SOUZA, 2001). The saliva flow rate of each subject was evaluated by measuring the volume of the saliva's rest for 5 min (OHASHI et al., 1999). Tongue-coating accumulation was assessed by visual examination based on the recommended criteria by Kojima (1985). Tongue-coating of volunteers was collected with Kolbe's cleaner (Kolbe ${ }^{\circledR}$, Bahia/Brazil), placed in sterile container and re-suspended (1:100) in phosphate/phosphate buffer $0.15 \mathrm{mM} \mathrm{pH} \mathrm{7.4.} \mathrm{All} \mathrm{the}$ samples were frozen stored at $-80^{\circ} \mathrm{C}$ until their use. In order to remove the debris, saliva and tongue-coating samples were centrifuged at 1,000 $\mathrm{x}$ g/15 $\mathrm{min}$ and an aliquot (500 $\mu \mathrm{L} /$ triplicates) was also used (GENESTRA et al., 2003;2004).

\section{Nitrite quantification}

$\mathrm{NO} / \mathrm{NO}_{2}^{-}$from saliva and tongue-coating supernatants was measured spectrophotometricaly by adding Griess reagent $(0.1 \% \mathrm{~N}-1$-naphtylethylenediamine in $5 \%$ phosphoric acid and 1\% sulfanilamide) to the same volume of the supernatants. After 10-15 minutes at room temperature, the absorbance of the chromophore was measured at $543 \mathrm{~nm}$ (Coleman Spectophotometer/England). Nitrite concentrations were estimated by comparison with a standard curve prepared with sodium nitrite. Unless otherwise stated, all reagents were purchased from Sigma Chemical Company (St. Louis, MO) (KOJIMA, 1985; GREEN et al., 1982; OHASHI et al., 1999; NAZARETYAN et al., 2000; GENESTRA et al., 2003).

\section{Statistical analysis}

The data are expressed with a \pm standard error of its meanings (SEM) for all parameters measured. The analysis were performed with a commercially statistical package Instat 5.0. Comparisons between groups were performed by using Students' $t$ and ANOVA test as appropriate. The Pearson rank test was used to asses the correlation between two variables, with $\mathrm{p}<0.05$ considered as significant.

\section{Results}

The results obtained pointed the direction of $\mathrm{NO} / \mathrm{NO}_{2}{ }^{-}$in mixed saliva of $98 \%$ of volunteers, with great individual variation, corroborating previous data (NISHANIAN et al., 1998; OHASHI et al., 1999; NAZARETYAN et al., 2000). The results showed that tobacco or ethanol, separately (Figure 1a and 1b), do not contribute significantly for the increase of $\mathrm{NO} / \mathrm{NO}_{2}{ }^{-}$concentration in the mixed saliva $(\mathrm{p}=0.19)$. However, the association tobacco/alcohol point positive correlation ( $\mathrm{p}=0.04$ ) between the increase of the concentration of nitrogen radicals in the mixed saliva in order to favour tobacco/alcohol users (Figure 1c), in comparison with the control group (non-smokers/non-drinkers). The $\mathrm{NO} / \mathrm{NO}_{2}{ }^{-}$ concentration in the tongue-coating possesses high concentration of anaerobic bacteria, beyond it has a lesser solubility than saliva.

\section{Discussion}

Saliva and oral mucosa transudates are the main components of oral fluids mixture. Saliva is a complex mixture of several salivary glands secretions and oral mucosa transudates (also called gingival crevicular fluids) is the fluid derived from the transport of serum components through the oral mucosa in the mouth, but previous analysis empathizes that they are distinct body fluids.

When we analyze the levels of $\mathrm{NO} / \mathrm{NO}_{2}{ }^{-}$in the mixed saliva of smokers in comparison with non smoking subjects, we do not find significant differences, the same been found when 
we compare the concentration of this radical between non drinkers/non drinkers. However, when analyzing the concentration of $\mathrm{NO}_{2}{ }^{-}$in the mixed saliva of smokers/drinkers in comparison with non smokers/non drinkers, we observed a significative increase in order to favour the first group. This data are important, since some works related the relation of the NO concentration with citotoxicity, angiogenesis, mutagenicity and metastasis of head and neck tumors (FARIAS-EISNER et al., 1994; ROSBE et al., 1995). Furthermore, Franceschi's group (1992) demonstrated that the association smoking/alcohol is a factor of risk to oral cancer (especially of wooden floor of mouth, gingival and tongue); some works also detaches that the risk of oral cancer is 14 times higher in subjects that smoke 10 or more cigarettes/day, mainly in reference to the tongue's cancer (DU et al., 1999). A possible explanation demonstrated by Squier and collaborators (1985) is that the alcohol increases the carcinogenic penetration through the oral mucosa, and possibly the NO can participate modulating important biochemical interactions. Interestingly, a correlation was described between polymorphism of the iNOS gene (exon 16) and the tobacco use (SHEN et al., 2002). Such alteration increases the susceptibility directly to some types of cancer, since it provokes changes of amino acid codification, especially serine by leucine, causing changes of antigenic recognition (FARIAS-EISNER et al., 1994). Such data increase the perception that, in fact, the NO consists in an important mediator of citotoxic/citoprotective activity related to oral physiopathology.

Human nitrite intake and metabolism have received considerable interest because nitrite formation in saliva is suspected to be involved in N-nitrosamine carcinogenesis in the acid environment. Tyrosine nitration is a well-established protein modification that occurs in disease states associated with oxidative stress and increased NOS activity. Nitration of specific tyrosine residues has been reported as to affect protein structure and function, suggesting that 3-nitrotyrosine formation may not only be a disease marker but may also be involved in the pathogenesis of some diseases and in normal regulatory processes. A number of investigations have indicated that the oral micro flora plays a major role in nitrate reduction, and several nitrite-producing organisms in human saliva have been identified, including, including Veillonella spp., Staphylococcusss aureus and Staphylococcus epidermidis, Nocardia spp., Corynebacterium pseudodiphtheriticum and Fusobacterium nucleatum (TANNENBAUM et al., 1974; NIKOV et al., 2003). Our results are according with other studies that demonstrated that saliva contains substantial concentrations of nitrite derived from the enterosalivary recirculation of dietary nitrate (OHASHI et al., 1999; NAZARETYAN et al., 2000).

These work findings also showed a low $\mathrm{NO} / \mathrm{NO}_{2}{ }^{-}$production (below $0.1 \mathrm{mmol} / \mathrm{l}$ ) from the tongue-coating, corroborating the data demonstrated by Li's group (1997), which studied the nitrite content on rat tongues, specially on anterior surface. These mechanisms occur because dietary nitrate is metabolized to nitrite by bacterial flora only on the posterior surface of the tongue leading to increased salivary nitrite concentrations. The tongue depths and the density of facultative anaerobic bacteria can results in a steep gradient in oxygen tension due to bacterial respiration. Interestingly, in vivo, Wang's group (1998) demonstrates changes on NO production by smoking, suggesting that the vascular endothelial cells could be damaged severely. Lohinai and collaborators (2001) showed an increase of NO production in periodontitis in rat model, and they suggested that NO-derivate nitrating species are formed basally in the gingivomucosa tissue and act as bactericidal agents, that when overproduced in periodontal disease, may induce host tissue injury (KONTTINEN et al., 1997; LOOMS et al., 2002; PANNALA et al., 2003). However, to date, few information has been published regarding the relationship between NO content in the mouth and smoking/alcohol habits. Dietary and metabolic nitrate is distributed from the blood to the saliva by active uptake in the salivary glands, and it is reduced to nitrite in the oral cavity by the action of certain bacteria. 
Although, the role of salivary NO in normal physiology is still unknown. The Ohashi's and collaborators (1999) findings suggest that excessive salivary NO plays a potential role in modifying oral mucosa diseases as a physiopathological regulator.

Although the $\mathrm{NO} / \mathrm{NO}_{2}{ }^{-}$measured in the mixed saliva and tongue coating does not serve as absolute index for the determination of the cytotoxic potential of this molecule, its mensuration consisting then in a additional factor to be analyzed in studies of oral injuries. Since the alcohol increases the carcinogenic compounds penetration through an oral mucosa, the higher concentration of $\mathrm{NO} / \mathrm{NO}_{2}{ }^{-}$in the mixed saliva - but not on the tongue-coating- of tobacco/alcohol users is as relevant, since literature has considered that these free nitrogen radicals, representing a group of essential components of the pathogenic route of oral ulcerative injuries (ROSBE et al., 1995).

Acknowledgements: We are indebted to all of the persons who donated samples. We would like to thanks Dr. Ana Christina Kolbe, Bad Breath Brazilian Association and Ms Fátima A. R. Lopes, Oswaldo Aranha Foundation/Volta Redonda/RJ. We are also grateful to Mrs Maria Cecília Fontainha de Almeida Gama, Dr. Juliana Chiarello-Nascimento, Nurse Damiana Guedes-Silva, Technician Lourival Dias Pereira and Dr. Loreley Luderer's group, Laboratory of Pathology/Dentistry Course, Oswaldo Aranha Foundation/Volta Redonda/RJ, who gave excellent support and assistance. This work was supported by Oswaldo Aranha Foundation/FOA.

\section{References}

- $\quad$ BENTZ BG, PELZER HJ, HAINES GK, HANSON DG, LINGEN MW, RADOSEVICH JA. Nitric oxide synthase type 3 is increased in squamous hyperplasia, dysplasia, and squamous cell carcinoma of the head and neck. Ann Otol Rhinol Laryngol; 108: 781-87, 1999.

- DU X, SQUIER CA, KREMER MJ, WERTZ PW. Penetration of N-nitrosonornicotine (NNN) across oral mucosa in the presence of ethanol and nicotine. J Oral Patholl Med; 29: 80-85, 1999.

- $\quad$ FARIAS-EISNER R, SHERMAN MP, AEBERHARD E. Nitric oxide is an important mediator in tumoricial activity in vivo. Proc Natl Acad Sci USA; 91: 9407-11, 1994.

- $\quad$ FRANCESCHI S, BARRA S, LA-VECCHIA C, BIDOLI E, NEGRI E, TALAMINI R. Risk factors for cancer of the tongue and mouth. Cancer ; 70: 2227-2233, 1992.

- GAVILANES J, MORO MA, LIZASOAIN I, LORENZO P, PÉREZ A, LEZA JC, ALVAREZVICENT JJ. Nitric oxide synthase activity in human squamous cell carcinoma of the head and neck. The Laryngoscope; 109: 148-52, 1999.

- GENESTRA M, SOUZA MR. Análise Comparativa da Capacidade-Tampão da Saliva por Titulometria: estudo comparativo. Rev. ABO Nacional , 9:28-32, 2001.

- GENESTRA M, ChIARELLO-NASCIMENTO J, SOUZA MR, MELO CN, GUEDES-SILVA D, LUDERER LA, CURY SEV, CARVALHO MVR, PEREIRA LD. Aspectos Preventivos da Mensuração da Concentração de Óxido Nítrico/Nitrito na Saliva de Fumantes e/ou Etilistas. Rev. ABOPREV, 6(1):33-42, 2003.

- GENESTRA M, SOUZA MR, CHIARELLO-NASCIMENTO J, KOLBE AC, ALVES FA, PEREIRA LD. Análise espectrofotométrica da placa bacteriana lingual (saburra lingual) e suas relações com a halitose. Rev. ABO Nacional , 12(1):53-61, 2004.

- $\quad$ GREEN LC, WAGNER DA, GLAGOWSKI J, SKIPPER PL, WISHNOK JS, TANNENBAUM SR. Analysis of nitrate, nitrite and $\left[{ }^{15} \mathrm{~N}\right]$ nitrate in biological fluids. Anal Biochem; 126: 131-138, 1982. 
- KOJIMA K. Clinical studies on the coated tongue. Japanese J Oral Maxilofac Surg; 31: 1659-1676, 1985.

- KONTTINEN YT, PLATTS LA, TUOMINEN S. Role of nitric oxide in Sjögren's syndrome. Arthritis Rheum; 40: 875-83, 1997.

- LI H, DUNCAN C, TOWNEND J, KILLHAM K, SMITH LM, JOHNSTON P, DYKHUIZEN R, KELLY D, GOLDEN M, BENJAMIN N, LEIFERT C. Nitrate-reducing bacteria on rat tongues. App. Environ Microbiol; 63: 924-930, 1997.

- LOHINAI Z, STACHLEWITZ R, VIRÁG L, SZÉKELY AD, HASKÓ G, SZABO C. Evidence for reactive nitrogen species formation in the gingivomucosal tissue. J Dent Res; 80: 470-75, 2001.

- LOOMS D, TRITSARIS K, PEDERSEN AM, NAUNTOFTE B, DISSING S 2002. Nitric oxide in salivary glands. J Oral Pathol Med; 31: 569-584, 2002.

- MONCADA S, PALMER RMI, HIGGS EA. Nitric oxide: physiology, pathophisiology and pharmacology. Pharmacol Rev; 43:109-142, 1991.

- NAZARETYAN Y, NARIMANYAN MZ, MARTIROSSYAN TV, GASPARYAN AY. Shifts in the contents of nitric oxide in saliva of bronchial asthmatic patients under conditions. Pulmonology; 10: 3336, 2000.

- NIKOV G, BHAT V, WISHNOK JS, TANNENBAUM SR. Analysis of nitrated proteins by nitrotyrosine-specific affinity probes and mass spectrometry. Anal Biochem ; 320:214-222, 2003.

- $\quad$ NISHANIAN P, AZIZ N, CHUNG J, DETELS R, FAHEY JL. Oral fluids as an alternative to serum for measurement of markers of immune activation. Clin Diagn Lab Immunol; 5: 507-512, 1998.

- OHASHI M, IWASE M, NAGUMO M. Elevated production of salivary nitric oxide in oral mucosal diseases. J Oral Pathol Med; 28: 355-359, 1999.

- $\quad$ PANG B, WENG X, WANG C. The correlactive study on nitric oxide and cotinine nicotine metabolite in smokers urine. Zhonghua Jie He He Hu Xi Za Zhi; 21:215-17, 1998.

- PANNALA AS, MANI AR, SPENCER JP, SKINNER V, BRUCKDORFER KR, MOORE KP, RICEEVANS CA. The effect of dietary nitrate on salivary, plasma, and urinary nitrate metabolism in humans. Free Radic Biol Med; 34: 576-84, 2003.

- $\quad$ ROSBE KW, PRAZMA J, PETRUSZ P, MIMS W, BALL SS, WEISSLER MC. Immunohistochemical characterization of nitric oxide synthase activity in squamous cell carcinoma of the head and neck. Head and Neck Surgery; 113: 541-549, 1995.

- SHEN J, WANG R, WANG L, WANG Z, XING H, WANG B, LI M, HUA Z, WANG J, GUO C, WANG X, XY X. Study on the relationship between susceptibility of stomach neoplasm cancer and polymorfism of inducible nitric oxide synthase gene. Zhonghua Liu Xing; 23: 374-377, 2002.

- SOUZA MR \& GENESTRA M. Características biofisiológicas e teorias do envelhecimento: aspectos gerais de interesse para o odontogeriatra. Rev. ABO Regional Valença, 2(2): 13-20, 2003.

- SQUIER CA, COX P, HALL BK. Enhanced penetration of nitrosonornicotine across oral mucosa in the presence of ethanol. Oral Med; 10: 76-279, 1985.

- TANNENBAUM SR, SINSKEY AJ, WEISMAN M, BISHOP W. Nitrite in human saliva. Its possible relationship to nitrosamine formation. J Natl Cancer Inst; 53: 79-84, 1974. 


\section{Legends to Figures}

Figure a: $\mathrm{NO} / \mathrm{NO}_{2}{ }^{-}$concentration in the mixed saliva and tongue-coating of smokers and non smokers. The results showed that tobacco does not contribute significantly for the increase of the $\mathrm{NO}$ concentration. The $\mathrm{NO} / \mathrm{NO}_{2}{ }^{-}$concentration in the tongue-coating is significantly worthless, in comparison with its concentration in mixed saliva.

Figure b: $\mathrm{NO} / \mathrm{NO}_{2}{ }^{-}$concentration in the mixed saliva and tongue-coating of drinkers (ethilism habits) and non-drinkers. The results showed that alcohol does not contribute significantly for the increase of the $\mathrm{NO}$ concentration. The $\mathrm{NO} / \mathrm{NO}_{2}{ }^{-}$concentration in the tongue-coating is significantly lower, in comparison with its concentration in mixed saliva.

Figure c: $\mathrm{NO} / \mathrm{NO}_{2}{ }^{-}$concentration in the mixed saliva and tongue-coating of smokers/drinkers and non smokers/non drinkers. The association tobacco/alcohol points positive correlation between the increase of the concentration of nitrogen radicals in the mixed saliva (but not in tongue-coating) to favor of tobacco/alcohol users. 


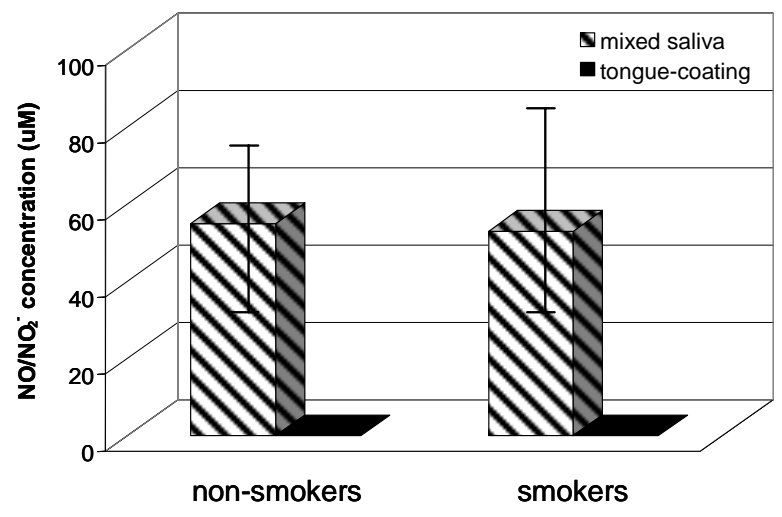

a)

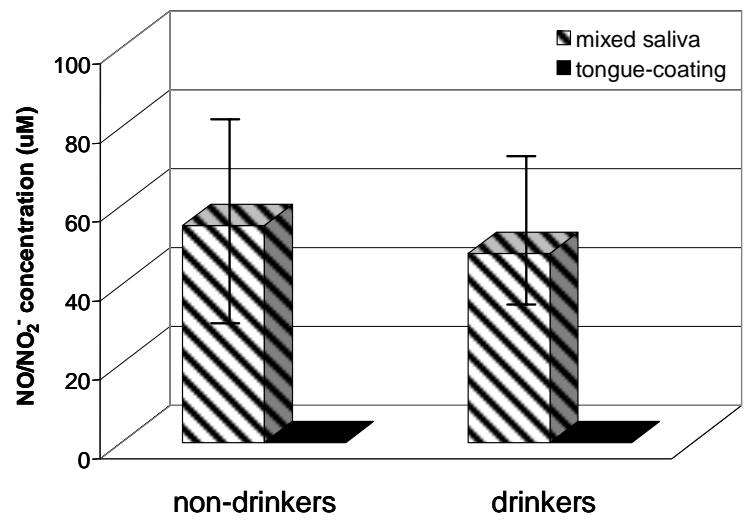

b)

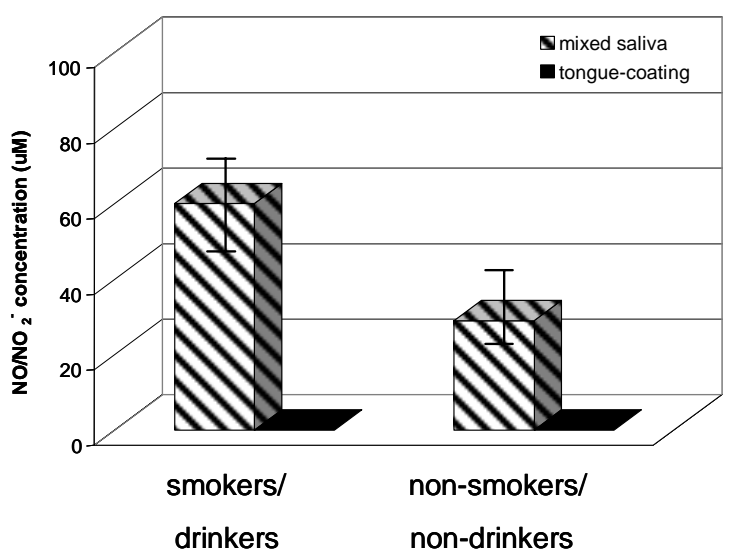

c)

\section{Figure 1}

\section{Informações bibliográficas:}

Conforme a NBR 6023:2002 da Associação Brasileira de Normas Técnicas (ABNT), este texto científico publicado em periódico eletrônico deve ser citado da seguinte forma:

SOUZA, Marise Ramos de; GENESTRA, M. S. . Tongue-coating and mixed saliva obtained from smokers and/or drinkers: nitric oxide/nitrite contents. Cadernos UniFOA, Volta Redonda, ano 1, $\mathrm{n}^{\circ}$. 1, jul. 2006. Disponível em:

$<$ http://www.unifoa.edu.br/pesquisa/caderno/edicao/01/121.pdf > 